\title{
Effect of fertilization on the physiological maturation of sesame seeds ${ }^{1}$
}

\author{
Erivan Isídio Ferreira², Márcio Dias Pereira ${ }^{2}$, \\ Aldifran Rafael de Macedo 2 , Edimar Rodrigues Soares ${ }^{3}$
}

\section{ABSTRACT}

Fertilization and harvest time may influence the formation and maturation processes, as well as the physiological quality of seeds. This study aimed at evaluating the effect of fertilization on the physiological maturation of sesame seeds. The following variables were evaluated: fruit color, dry mass and water content of fruits and seeds, germination, first germination count, germination speed, emergence and emergence speed. No significant fertilization effect was observed on fruit maturation for water content or dry mass. However, there was significance for these variables in the seeds. The harvest time had a significant effect on water content and dry mass of fruits and seeds. For the variables that evaluated the seed viability and vigor, both the fertilization and harvest time influenced the physiological maturation. The physiological maturity of the sesame seeds, whose plants were grown with and without fertilization, was reached between 52 and 54 days after anthesis, when the fruits were classified as yellow-greenish $7.5 \mathrm{Y} 8 / 6$ and yellow to yellow-red 10.R 4/6.

KEYWORDS: Sesamum indicus L.; plant nutrition; harvest season; physiological maturity.

\section{INTRODUCTION}

Correctly determining the harvest point is essential for crops such as sesame, because the longer the plant stays in the field after maturation, the greater the loss of seeds during harvest. Losses can reach up to $50 \%$, if harvest is not carried out in the appropriate time. Thus, seed harvest should be carried out as close as possible to the time of physiological maturity (Arriel et al. 2007).

Due to harvest losses, plants must be cut before the end of their cycle, while fruits are still closed and the plant presents greater fruit maturation uniformity.

\section{RESUMO}

Efeito da adubação na

maturação fisiológica de sementes de gergelim

A época de fertilização e colheita podem influenciar no processo de formação, maturação e qualidade fisiológica das sementes. Objetivou-se avaliar o efeito da adubação na maturação fisiológica de sementes de gergelim. As seguintes variáveis foram avaliadas: coloração dos frutos, massa seca e teor de água de frutos e sementes, germinação, primeira contagem de germinação, velocidade de germinação, emergência e velocidade de emergência. Para o teor de água e massa seca, não houve efeito significativo da adubação na maturação dos frutos. No entanto, ocorreu significância nessas variáveis para as sementes. O período de colheita promoveu efeito significativo no teor de água e massa seca de frutos e sementes. Para as variáveis que avaliaram a viabilidade e o vigor das sementes, a adubação e a época de colheita influenciaram na maturação fisiológica. A maturidade fisiológica das sementes de gergelim, cujas plantas foram produzidas com e sem adubação, foi alcançada entre 52 e 54 dias após a antese, quando os frutos foram classificados com coloração amarela-esverdeada 7.5 Y 8/6 e amarela a amarela-vermelha 10.R 4/6.

PALAVRAS-CHAVE: Sesamum indicus L.; nutrição vegetal; época de colheita; maturidade fisiológica.

When this does not occur, there may be a reduction in the final grain yield, losses by degranulation and deterioration of seeds in the field (Arriel et al. 2007). Thus, establishing the ideal point for harvesting sesame seeds is of extreme importance to preserve the production quality, as well as for the formation and maturation processes of its fruits and seeds, thus ensuring quality for the propagation material.

Among the factors that influence the development of this oilseed, fertilization is a controversial subject, with positive results in certain environments and cultivars and negative results in other situations (Porto et al. 2013). Plants must have 
the adequate amount of nutrients available in the soil to reach their full potential (Lima 2012). Sesame plants extract relatively high amounts of nutrients from the soil, with fruits presenting 33-60\% of $\mathrm{N}, \mathrm{P}$ and $\mathrm{K}$ extracted from the soil at harvest time. Therefore, much of the absorbed nutrients is directed to the fruits and seeds, during their formation process (Beltrão 2001).

The demand for nutrients increases even more in fields destined to seed production. The formation of embryo and reserve tissues, as well as their chemical composition, may be influenced by the availability of nutrients to plants. Poor plant nutrition may not only reduce yield, but also the physiological quality of seeds (Carvalho \& Nakagawa 2012).

It is known that seedlings vigor is responsible for seed quality. Plant nutrition, which in turn is directly related to the chemical composition of seeds, is one of the main limitations for high seedling vigor (Marcos Filho 2016). Thus, it is necessary to establish the influence of fertilization for each crop on the process of seed formation and maturation. For sesame, fertilization increases the seed number and size, if compared to its cultivation on unfertilized and low fertility soils in the Northeast region of Brazil (Perin et al. 2010). However, this study did not evaluate the effect of fertilization on the maturation process and physiological quality of seeds.

Thus, this study aimed at evaluating the effect of fertilization on the physiological maturation process of sesame seeds.

\section{MATERIAL AND METHODS}

The experiment was conducted at the experimental farm of the Universidade Federal do Rio Grande do Norte, in Macaíba, Rio Grande do Norte state, Brazil (5'53'30.67''S and 35'21'41.00'W).

Fruit and seed quality analyzes were performed using sesame seeds (CNPA G4 cultivar) produced in the harvest year of 2015. Seeds were stored in PET bottles, which were kept sealed in a refrigerator for 12 months, until the sowing time (July 2016), being sown in shallow grooves ( $1 \mathrm{~cm}$ deep), with thinning at 20 days after emergence, leaving 10 plants per meter.

Fertilization was performed according to the soil analysis (Table 1), using $5 \mathrm{~m}^{3} \mathrm{ha}^{-1}$ of cow manure, $20 \mathrm{~kg} \mathrm{ha}^{-1}$ of FTE BR 12 (B: $2.5 \%$; Cu: $7.5 \%$; Mn: $12.0 \%$; Zn: $5.0 \%$; Fe: $6.0 \%$ ), $10 \mathrm{~kg} \mathrm{ha}^{-1}$ of $\mathrm{N}$ and $30 \mathrm{~kg} \mathrm{ha}^{-1}$ of $\mathrm{K}_{2} \mathrm{O}$ at the sowing time (Beltrão 2001). At 30 days after emergence, a second dose of $20 \mathrm{~kg} \mathrm{ha}^{-1}$ of N was applied. Management was carried out with sprinkler irrigation (Beltrão 2001).

A randomized block design with four replications was used in the field. The treatments consisted of a 2 × 13 factorial scheme, for determining the fruit dry mass and water content variables. The first factor was the absence or presence of fertilization and the second one the seed harvest period, which took place from the anthesis until 56 days after the floral opening. It was not possible to use the same factorial scheme for all the other variables, since the seeds were not yet able to undergo the vigor tests. The $2 \times 9$ factorial scheme was used for determining the seed dry mass and water content; $2 \times 8$ for germination, first germination count and germination speed index; and 2 x 4 for emergence and emergence speed index. The experimental plots consisted of six lines of $4.0 \mathrm{~m}$ each (disregarding the two edge rows), with spacing of $1.0 \mathrm{~m}$ between rows.

For the sampling of fruits and seeds, 20 flowers were randomly selected and marked by repetition, immediately after anthesis. The first marking was carried out at 40 days after emergence (DAE), when the plants began to present enough flowers to be marked. The fruits resulting from the marked flowers in each plot were removed from the main stem and branches at each collection, and then immediately taken to the laboratory, where the physical and physiological quality analyzes were carried out.

The intention was to include the premature, optimum and late maturation stages, at intervals of 7 days, until 42 days after anthesis (DAA), and from there at intervals of 2 days to 56 DAA, totaling 13 collection periods.

Table 1. Chemical and physical properties of the soil (0-20 cm layer) cultivated with sesame plants.

\begin{tabular}{|c|c|c|c|c|c|c|c|c|c|}
\hline $\mathrm{pH}$ & $\mathrm{Ca}$ & $\mathrm{Mg}$ & $\mathrm{Al}$ & $\mathrm{H}+\mathrm{Al}$ & $\mathrm{P}$ & $\mathrm{K}$ & Sand & Clay & Silt \\
\hline $\mathrm{H}_{2} \mathrm{O}$ & & 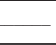 & & & -1 & & & $\mathrm{~g} \mathrm{~kg}^{-1}$ & \\
\hline 6.67 & 2.32 & 0.9 & 0.0 & 0.67 & 118 & 80 & 897 & 20 & 83 \\
\hline
\end{tabular}


The fruits were classified at each harvest regarding their color (Munsell 1976). Next, the water content (\% moisture basis) was determined using the oven method at $105 \pm 3{ }^{\circ} \mathrm{C}$, for $24 \mathrm{~h}$ (Brasil 2009), at 7 DAA for fruits and 35 DAA for seeds. Fruit and seed dry mass were evaluated along with the water content determination, with results expressed in grams.

The germination test was performed with seeds harvested starting at $42 \mathrm{DAA}$, in gerbox plastic boxes, with four replicates of 50 seeds, distributed over two sheets of Germitest ${ }^{\circledR}$ paper. The paper was moistened with distilled water at the proportion of 2.5 times the weight of the dry substrate. The boxes with seeds were kept in a BOD germinator, at an alternating temperature of $20-30^{\circ} \mathrm{C}$, with $8 \mathrm{~h}$ of light during the exposure period, at $30{ }^{\circ} \mathrm{C}$. Germinated seed evaluations were carried out at 3 and 6 days after sowing (DAS), with results expressed as percentage of normal seedlings (Brasil 2009). The first germination count was performed together with the germination test, at 3 DAS (Brasil 2009). Emergence speed was determined together with the germination test by calculating the germination speed index (Maguire 1962). For that, daily counts of the seedlings that showed primary roots were carried out during 6 days.

The sand emergence test was performed based on the harvest at 50 DAA. The seeds were distributed into plastic trays $(35 \mathrm{~cm}$ wide, $55 \mathrm{~cm}$ long and $13 \mathrm{~cm}$ deep) filled with medium granulometric sterilized sand, in four replicates of 50 seeds, spaced at $3 \mathrm{~cm} \times 10 \mathrm{~cm}$, with average sowing depth of $1 \mathrm{~cm}$. The percentage of seedlings emerged at 14 DAS was determined. Along with the emergence test, emergence speed was determined through the emergence speed index (Maguire 1962), for which daily seedling counts were performed over 14 days. Seedlings whose cotyledons appeared on the soil surface were considered as emerged.

The data were submitted to analysis of variance by the F test ( $1 \%$ and $5 \%$ ) and means were submitted to regression analysis, with respect to harvest time. The AgroEstat software was used for statistical analyzes (Barbosa \& Maldonado Júnior 2015). Data obtained as percentages were transformed into sine $\operatorname{arc} \sqrt{ }(\mathrm{x} / 100)$.

\section{RESULTS AND DISCUSSION}

Fruit staining classification, according to the Munsell's chart (1976), during the maturation process, allowed the identification of different colors in the harvest periods (Figure 1). The fruits were classified as greenish to green-yellow $7.5 \mathrm{GY} 6 / 6$, from 7 to $28 \mathrm{DAA}$. At $35 \mathrm{DAA}$, they presented a greenish to green-yellow 7.5 GY 7/6 color. From 42 to $44 \mathrm{DAA}$, a yellow to green-yellow $10.0 \mathrm{GY} 7 / 6$ color, and $8 / 6$ at 46,48 and 50 DAA. In the period during which the physiological maturity of the seeds was observed, sesame fruits were classified as greenish to yellow 7.5 Y 8/6 (52 DAA) and yellow to yellow-red 10.R 4/6 (54 DAA). The fruits were classified as yellow to yellow-red 10.R 5/6 in the last stage evaluated at 56 DAA.

The fruit color is important to help to identify the period of physiological maturity of seeds, as already verified for several species (Guimarães \& Barbosa 2007, Lima et al. 2012, Rubio et al. 2013). According to Lucena et al. (2013), who did not use an official classification for characterizing the fruit colors during maturation, seeds from fruits harvested after they had acquired a yellowish or light brown staining presented a greater viability and vigor. The results obtained in this study corroborate this statement, since seeds harvested at 52-54 DAA had the highest physiological quality and dry mass. Also, in the present study, fruits presented the same appearance to that described by Lucena et al. (2013).

This information is important, since it can help to decide the ideal moment for harvesting sesame plants. This ensures the quality of the seeds harvested, avoiding seed losses, which can reach up to $50 \%$ (Arriel et al. 2007). This is essential, considering that sesame fruits open after ripening, releasing the seeds into the environment (Oplinger et al. 1997).

The analysis of variance for dry mass and water content of the sesame fruits is presented in Table 2. No significant effect of fertilization and fertilization $\mathrm{x}$ harvest period were found on fruit dry mass and water content. For these variables, only the harvest period had a significant effect. The results of the $\mathrm{F}$ test indicate that there was no significant effect of fertilization on dry mass. However, it promoted a significant influence on seed water content. A significant effect of harvest time and fertilization $\mathrm{x}$ harvest period was also observed for seed dry mass and water content.

Sesame fruits show a gradual accumulation of photoassimilates along their maturation, reaching their maximum dry mass between 42 and 35 DAA (Figure 2a), for treatments with and without 
fertilization, respectively, showing a downward trend right after. According to Marcos Filho (2016), the initial phase of fruit growth is characterized by an accelerated accumulation of mass, as this is a stage in which many cellular divisions occur, followed by a phase with a predominance of cellular expansion, and finally maturation, reaching maximum fruit mass.

Fruit water content (Figure 2c) had a high percentage of moisture at the beginning of growth, both for fruits from plants submitted to the treatment without fertilization and from fertilized plants. However, it is possible to verify that the drop in water content becomes more pronounced after 35 DAA.

According to Lucena et al. (2013), fruits start the maturation process after they reach their final size, when water content is still above $50 \%$. After maturity, naturally progressive losses of moisture occur, resulting in a smaller volume of fresh mass. Therefore, water loss is a natural and important


Figure 1. Color of sesame fruits throughout their development, in plants grown without (1) and with fertilization (2). Greenish to green-yellow $7.5 \mathrm{GY} 6 / 6$ staining of the sesame fruits at 7 (A and B), $14(\mathrm{C}$ and D), $21(\mathrm{E}$ and F) and $28(\mathrm{G}$ and $\mathrm{H})$ days after anthesis (DAA); greenish to green-yellow 7.5 GY 7/6 (I and J) at 35 DAA; yellow to green-yellow $10.0 \mathrm{GY} 7 / 6$ at 42 (K and $\mathrm{L}$ ) and $44(\mathrm{M}$ and $\mathrm{N}) \mathrm{DAA} ; 8 / 6$ at $46(\mathrm{O}$ and $\mathrm{P}), 48(\mathrm{Q}$ and $\mathrm{R}$ ) and 50 (S and T) DAA; greenish yellow 7.5 Y 8/6 at 52 (U and V) DAA; yellow to yellow-red 10.R 4/6 at 54 and 5/6 (Y and Z) at 56 days post anthesis.

Table 2. Analysis of variance showing F values for dry mass (DM) and water content (WC) for sesame fruits and seeds, in different harvest periods, for plants cultivated with and without fertilization.

\begin{tabular}{|c|c|c|c|c|c|c|}
\hline \multirow{2}{*}{ Source of variation } & \multicolumn{3}{|c|}{ Fruits } & \multicolumn{3}{|c|}{ Seeds } \\
\hline & $\mathrm{DF}$ & $\mathrm{DM}(\mathrm{g})$ & WC (\%) & DF & $\mathrm{DM}(\mathrm{g})$ & WC (\%) \\
\hline Fertilization $(\mathrm{F})$ & 1 & $0.04^{\mathrm{ns}}$ & $0.95^{\mathrm{ns}}$ & 1 & $15.73^{\mathrm{ns}}$ & $15.61 * *$ \\
\hline Harvest periods $(\mathrm{H})$ & 12 & $56.18 * *$ & $25.62 * *$ & 8 & $829.17 * *$ & $823.27 * *$ \\
\hline $\mathrm{F} \times \mathrm{H}$ & 12 & $0.65^{\mathrm{ns}}$ & $0.31^{\mathrm{ns}}$ & 8 & $37.29 * *$ & $36.95 * *$ \\
\hline Residue & 75 & & & 54 & & \\
\hline CV (\%) & & 14.44 & 16.78 & & 1.02 & 5.62 \\
\hline
\end{tabular}


phenomenon for fruits, as well as for maintaining the physiological quality of seeds.

In addition to the fruit characteristics, monitoring the seed development is also an important parameter for studying the physiological seed maturation. This can be done based on modifications that occur in some physical and physiological characteristics, such as size, water content, accumulated dry mass content, germination and vigor (Marcos Filho 2016).

Seeds from the treatment with fertilization had greater water proportions, in relation to the seed dry mass at 35 DAA, while the opposite occurred for the treatment without fertilization (Figures $2 b$ and $2 \mathrm{~d})$. Water plays a crucial role in seed formation, since it initially acts in the process of cell division and expansion (Ruan et al. 2012, Bewley et al. 2013).

Cell division and expansion determine the number and size of cells (Perrot-Rechenmann 2010). For this reason, seeds present a higher proportion
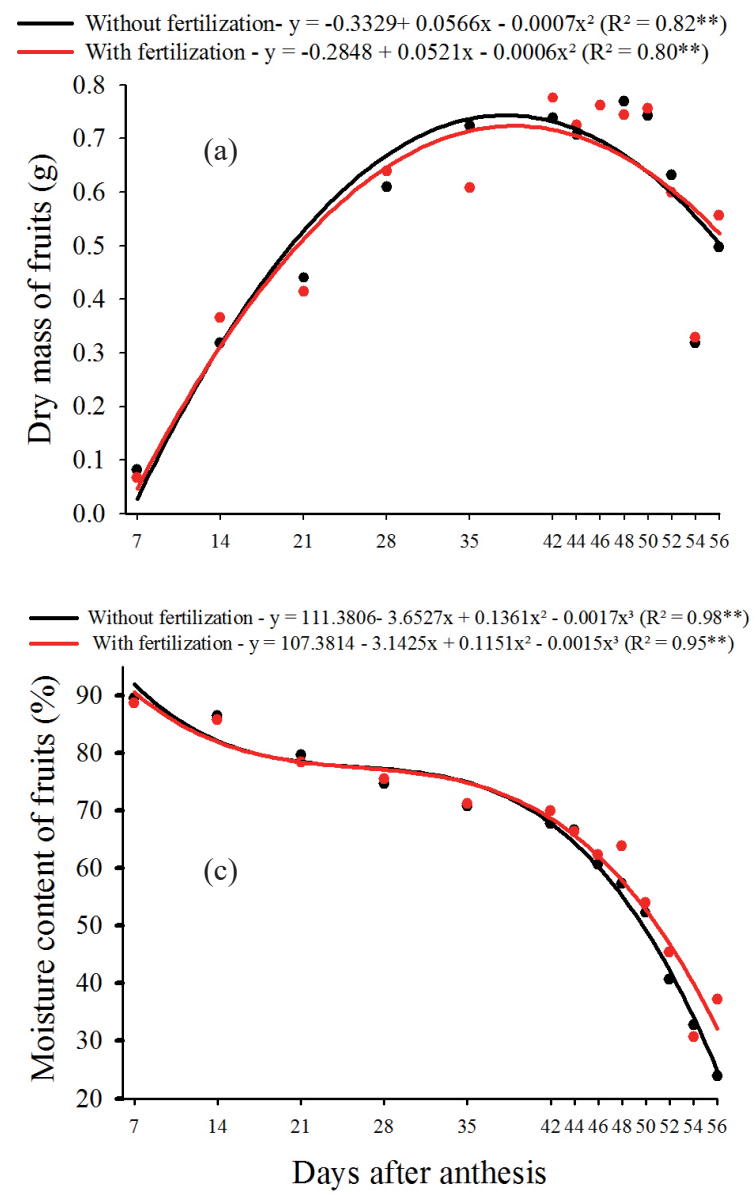

of fresh mass at the beginning of growth, due to the larger amount of water inside their cells, which will later be replaced by synthesized reserves such as carbohydrates, lipids and minerals (Carvalho \& Nakagawa 2012). In addition, water acts as a vehicle for the photosynthesis products that will be part of the seed tissues or will be stored as reserve (Barbedo \& Marcos Filho 1998).

Thus, it can be inferred that the greater proportion of water in the seeds of the treatment with fertilization at $35 \mathrm{DAA}$ is due to the greater number of divisions and cellular expansion in this treatment, which probably resulted in higher amounts of accumulated carbohydrates and minerals, meaning a better seed quality. This contributes to the hypothesis that a greater germination, higher seed germination speed index and higher emergence speed index are obtained in the treatment with fertilization.

It was observed that the dry mass of sesame seeds (Figure 2b) showed a tendency of increase
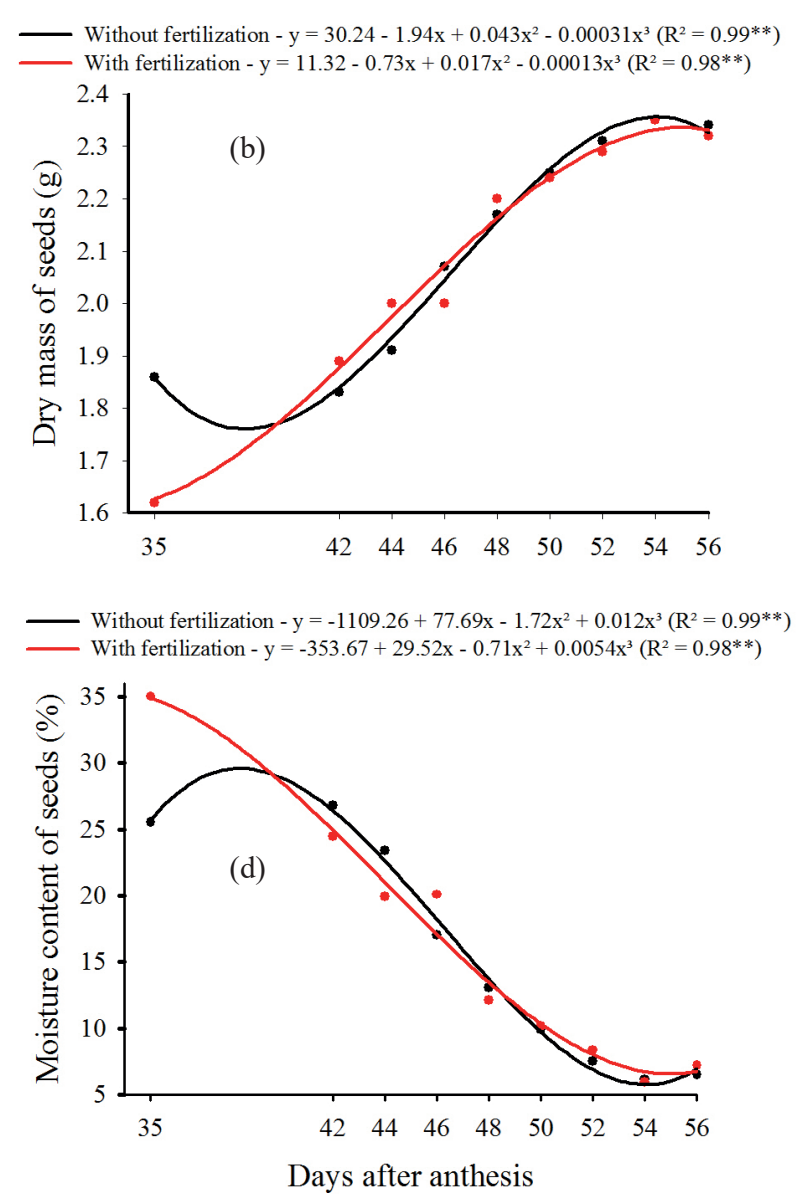

Figure 2. Sesame fruit (a) and seed (b) dry mass and fruit (c) and seed (d) water content throughout the maturation period, in plants cultivated with and without fertilization. 
from the first period analyzed (35 DAA), reaching its maximum value between 52 and 54 DAA, when it began to show a decline. According to Nobre et al. (2013), seed size increases rapidly after fertilization, reaching its maximum in a short time, in relation to the total duration of the maturation period. This rapid growth is due to the multiplication and development of embryo cells and reserve tissues. After reaching its maximum size, it decreases due to water losses in the seeds, and this reduction varies with species. Evaluating the maturation and physiological quality of the IAC-China cultivar of sesame seeds, Lago et al. (2001) found that the increase in seed dry mass occurred gradually, and after the peak there was a small drop, which remained practically constant, even in purposely delayed harvests. This differs from the results found in this study, in which a tendency of marked reduction in the values of this variable was observed after the maximum dry mass.

Identifying the period of greatest accumulation of photoassimilates in seeds also has a great practical importance in the field. According to Lucena et al. (2013), the maturation stage significantly influences the dry mass of sesame seeds, indicating that producers will have a decrease of up to $4 \%$ in grain yield, if the fruit is harvested before or after physiological maturity.

Similarly to fruits, the water content of sesame seeds (Figure 2d) presented a reduction throughout the period in which the harvests were carried out. However, this decrease was much more pronounced than in the fruit, reaching the lowest value at 54 DAA, with an average water content of $6.07 \%$, considered close to ideal or recommended for the safe storage of seeds (Almeida et al. 1999). In the case of sesame seeds, Queiroga et al. (2010) state that water content is inversely related to their quality.
As the seed dry mass increased (Figure 2b), its water content (Figure 2d) decreased. This explains why the size of the seed increases rapidly after fertilization, due to multiplication and development of the embryo cells and reserve tissues. After reaching the maximum level, the size decreases due to water losses by the seeds. In parallel, photoassimilates from the leaves are sent to the forming seeds, where they are transformed and reused for forming new cells, tissues and as future reserve material (Marcos Filho 2016).

Evaluating the characteristics of viability and vigor, a significant effect of fertilization was observed on the variables germination, seed germination speed index, emergence and emergence speed index. The exception occurred for the first germination count. No significances were found for the interaction fertilization $\mathrm{x}$ harvest period on germination, germination speed index or emergence (Table 3).

The germination of the sesame seeds reached its maximum point between 52 and 54 DAA (Figure 3a), when the plants were not fertilized, and between 52 and 56 DAA, when they were fertilized.

Crop management with harvest at the correct time is important for maintaining the quality of the seeds (Araújo et al. 2006, Smiderle \& Pereira 2008), preserving their maximum germination potential. From the maximum germination point (Figure 3a), which coincided with the point at which there was the maximum dry mass accumulation in the seed (Figure 2b), there was a tendency to decrease, probably indicating that, after reaching physiological maturity, the sesame seeds begin their deterioration process.

Similar results were obtained by Lago et al. (2001), who pointed out that germination percentages of the IAC-China cultivar of sesame seeds started to decrease after reaching a maximum dry mass, with

Table 3. Analysis of variance with the F values for germination (G), first germination count (FGC), seed germination speed index (GSI), emergence (E) and emergence speed index (ESI) of sesame seedlings at different harvest periods, in plants grown with and without fertilization.

\begin{tabular}{|c|c|c|c|c|c|c|c|}
\hline \multirow{2}{*}{ Source of variation } & \multicolumn{4}{|c|}{ Germination } & \multicolumn{3}{|c|}{ Emergence } \\
\hline & $\mathrm{DF}$ & G (\%) & FGC (\%) & GSI & DF & $\mathrm{E}(\%)$ & ESI \\
\hline Fertilization (F) & 1 & $23.74 * *$ & $3.23^{\mathrm{ns}}$ & $18.61 * *$ & 1 & $4.88^{*}$ & $15.55 * *$ \\
\hline Harvest period $(\mathrm{H})$ & 7 & $178.66^{* *}$ & $407.46^{* *}$ & $391.74 * *$ & 3 & $5.49 * *$ & $31.39 * *$ \\
\hline $\mathrm{F} \times \mathrm{H}$ & 7 & $2.07^{\mathrm{ns}}$ & $2.26^{*}$ & $1.40^{\mathrm{ns}}$ & 3 & $1.03^{\mathrm{ns}}$ & $4.61 *$ \\
\hline Residue & 45 & & & & 21 & & \\
\hline CV (\%) & & 8.73 & 8.49 & 5.73 & & 8.93 & 9.50 \\
\hline
\end{tabular}


a tendency of continuous decreasing. According to the authors, this may be an indication that seeds began their deterioration process after reaching physiological maturity.

First germination count (Figure $3 b$ ) indicates that the percentage of normal seedlings increased


throughout the maturation period, reaching the maximum germination between harvests carried out at 52 and 56 DAA, both for plants grown with and without fertilization. From this point, a downward trend begins in both treatments. Analyzing the vigor of black sesame seeds, using the first count test, Nobre et al. (2013) also observed an increase in vigor, as the harvests were being carried out, reaching a maximum level from which a tendency of reduced quality in the seeds was observed.

The behavior observed for the germination and first count are similar to the result obtained for the germination speed index (Figure 3c). In the two treatments tested (with and without fertilization), an increase in the vigor of the seeds was observed, with maximum values obtained between 52 and 54 DAA and, soon afterwards, the germination rate of the seeds decreased. This result confirms that the maturity point was reached in this period and, from
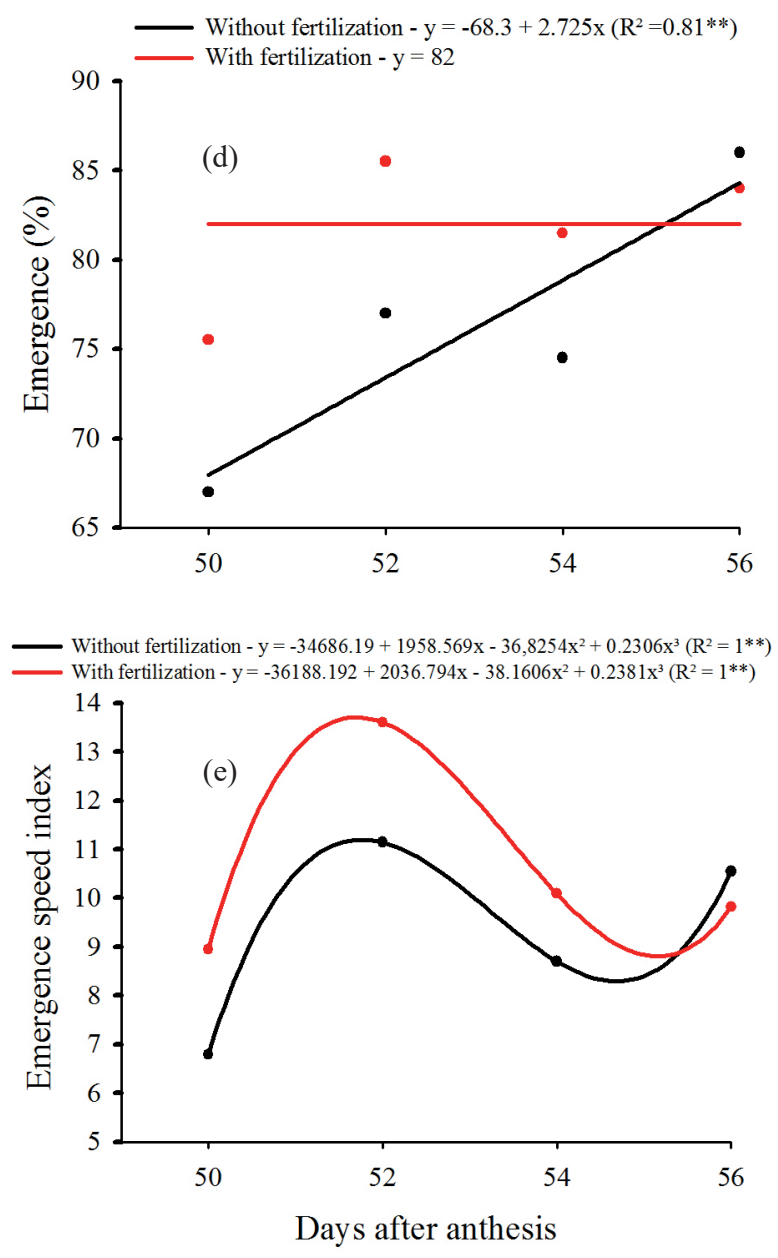

Figure 3. Germination (a), first germination count (b), seed germination speed index (c), emergence (d) and emergence speed index (e) of sesame seedlings throughout the maturation period, in plants cultivated with and without fertilization. 
that point on, its deterioration process began. The results obtained in the present study indicate that seeds remain in the maturing point for a short period, since the germination, first count and germination speed index decreased rapidly soon after seeds reached maximum viability and vigor.

Emergence in sand presented an exceptional linear growth pattern for the treatment without fertilization (Figure 3d). For seeds harvested in plants with fertilization, there was no variation of emergence over the period evaluated. However, it should be noted that the average emergence (Figure 3d) obtained in the treatment with fertilization, regardless of the harvest period, was $82 \%$, whereas, in the treatment without fertilization, an emergence of $84 \%$ was obtained only at 56 DAA. In other words, fertilization allowed the seeds to acquire a certain level of quality in a shorter time. This is due to the greater availability of nutrients in the plants that received fertilization. It is known that the nutritional requirement in the seed formation phase is intense. Considerable amounts of nutrients are stored for them in this phase, ensuring a proper formation of the reserve organ, and consequently influencing the metabolism and vigor of seeds (Carvalho \& Nakagawa 2012).

The emergence speed index indicated a higher seed vigor around 52 DAA, for seeds obtained both from plants with and without fertilization (Figure 3e). The emergence speed index of sesame seedlings used in this study shows the same pattern observed for the germination percentage, first germination count and germination speed index, with a tendency to increase throughout the maturation process. Seeds present their greatest vigor at the period of physiological maturity, when they have a superior performance, regarding the emergence of seedlings in the field, and a greater emergence speed index (Mattioni et al. 2012, Lucena et al. 2013).

The loss of seed quality after reaching physiological maturation is a natural process, and it mainly depends on the relative air humidity and the temperature to which they are exposed (Garcia et al. 2004). After physiological maturation, the period in which the seeds remain in the field is decisive for deterioration or loss of vigor (Delouche 1975). It is essential to be even more careful with this situation in the case of sesame, considering that the seeds are very sensitive to moisture, which should be kept at around $6 \%$ (Almeida et al. 1999).

\section{CONCLUSIONS}

1. Fertilization practices influence the maturation of sesame seeds by increasing the germination, germination speed and first germination count;

2. The physiological maturity of sesame seeds is reached between 52 and 54 days after anthesis.

\section{REFERENCES}

ALMEIDA, F. A. C.; FONSECA, K. S.; GOUVEIA, J. P. G. Natural drying of sesame and determination of equilibrium moisture. Revista Brasileira de Engenharia Agrícola e Ambiental, v. 3, n. 3, p. 343-348, 1999.

ARAÚJO, A. E. et al. Cultivo do gergelim. Campina Grande: Embrapa Algodão, 2006.

ARRIEL, N. H. C. et al. A cultura do gergelim. Campina Grande: Embrapa Algodão, 2007. (Circular técnica, 12).

BARBERDO, C. J.; MARCOS FILHO, J. Tolerância à dessecação em sementes. Acta Botanica Brasilica, v. 12, n. 2, p. 145-164, 1998.

BARBOSA, J. C.; MALDONADO JÚNIOR, W. AgroEstat: sistema para análises estatísticas de ensaios agronômicos, versão 2.0. Jaboticabal: FCAV, 2015.

BELTRÃO, N. E. M. O agronegócio do gergelim no Brasil. Campina Grande: Embrapa Informação Tecnológica, 2001. (Circular técnica, 3).

BEWLEY, J. D. et al. Seeds: physiology of development, germination and dormancy. 3. ed. New York: Springer, 2013.

BRASIL. Ministério da Agricultura, Pecuária e Abastecimento. Secretaria de Defesa Agropecuária. Regras para análise de sementes. Brasília, DF: MAPA/ ACS, 2009.

CARVALHO, N. M.; NAKAGAWA, J. Sementes: ciência, tecnologia e produção. 5. ed. Jaboticabal: Funep, 2012.

DELOUCHE, J. C. Pesquisa em sementes no Brasil. Brasília, DF: Agiplan, 1975.

GARCIA, D. C. et al. A secagem de sementes. Ciência Rural, v. 34, n. 2, p. 603-608, 2004.

GUIMARÃES, D. M.; BARBOSA, J. M. Coloração dos frutos como índice de maturação para sementes de Machaerium brasiliense Vogel (Leguminosae - Fabaceae). Revista Brasileira de Biociências, v. 5, n. 2, p. 567-569, 2007.

LAGO, A. A. et al. Maturação e produção de sementes de gergelim cultivar IAC-China. Pesquisa Agropecuária Brasileira, v. 36, n. 2, p. 363-369, 2001. 
LIMA, C. R. de. Physiological maturity of fruits and seeds of Poincianella pyramidalis (Tul.) L. P. Queiroz. Revista Brasileira de Sementes, v. 34, n. 2, p. 231-240, 2012.

LIMA, J. C. R. et al. Crescimento e desenvolvimento do gergelim BRS seda irrigado com níveis de água residuária e de abastecimento. 2012. 134 f. Dissertação (Mestrado em Produção Vegetal) - Universidade Estadual da Paraíba, Campina Grande, 2012.

LUCENA, A. M. A. et al. Qualidade de sementes de gergelim colhidas de frutos em diferentes estádios de maturação. Scientia Plena, v. 9, n. 6, p. 23-27, 2013.

MAGUIRE, J. D. Speed of germination: aid in selection and evaluation for seedling emergence and vigour. Crop Science, v. 2, n. 2, p. 176-177, 1962.

MARCOS FILHO, J. Seed physiology of cultivated plants. Londrina: Abrates, 2016.

MATTIONI, F. et al. Vigor de sementes e desempenho agronômico de plantas de algodão. Revista Brasileira de Sementes, v. 34, n. 1, p. 108-116, 2012.

MUNSELL, A. H. Munsell book of color. Baltimore: Kollmorgen, 1976.

NOBRE, D. A. C. et al. Qualidade da semente do gergelim preto (Sesamum indicum L.) em diferentes épocas de colheita. Revista Brasileira de Plantas Medicinais, v. 15, n. 2, p. 609-616, 2013.
OPLINGER, E. S. et al. Sesame: alternative field crops manual. 1997. Available at: <https://hort.purdue.edu/ newcrop/afcm/sesame.html >. Access on: 07 Jun., 2017.

PERIN, A.; CRUVINEL, D. J.; SILVA, J. W. Desempenho do gergelim em função da adubação NPK e do nível de fertilidade do solo. Acta Scientiarum Agronomy, v. 32, n. 1, p. 93-98, 2010.

PERROT-RECHENMANN, C. Cellular responses to auxin: division versus expansion. Cold Spring Harbor Perspectives in Biology, v. 2, n. 5, p. 1-15, 2010.

PORTO, V. C. N. et al. O gergelim e seu cultivo no semiárido brasileiro. Campina Grande: Embrapa algodão, 2013.

QUEIROGA, V. et al. Qualidade fisiológica e composição química das sementes de gergelim com distintas cores. Revista Agroambiente, v. 4, n. 1, p. 27-33, 2010.

RUAN, Y. L. et al. Molecular regulation of seed and fruit set. Trends in Plant Science, v. 17, n. 3, p. 656-665, 2012.

RUBIO, F. et al. Estádios de maturação do fruto no desempenho germinativo e teor de óleo de sementes de Jatropha curcas Linn. Semina: Ciências Agrárias, v. 34, n. 2, p. 663-668, 2013.

SMIDERLE, O. J.; PEREIRA, P. R. V. S. Épocas de colheita e qualidade fisiológica das sementes de arroz irrigado cultivar BRS 7 Taim, em Roraima. Revista Brasileira de Sementes, v. 30, n. 1, p. 74-80, 2008. 